Jurnal Teknologi Pendidikan, Vol. 10 No. 1 April 2017, p-ISSN; 1979-6692, e-ISSN: 2407-7437

\title{
PENGARUH STRATEGI PEMBELAJARAN DAN KEMAMPUAN BERPIKIR KREATIF SISWA TERHADAP HASIL BELAJAR KETERAMPILAN JAHIT DAN SULAM
}

\author{
Sri Susilawaty \\ Guru SMP Negeri 3 Tanjung Morawa, Sumatera Utara \\ srisusilawatys@gmail.com
}

\begin{abstract}
Abstrak: Penelitian ini bertujuan untuk mengetahui : hasil belajar Keterampilan jahit dan sulam yang diajar dengan menggunakan strategi pembelajaran kooperatif tipe jigsaw dibandingkan siswa yang diajarkan dengan menggunakan strategi pembelajaran ekspositori; hasil belajar Keterampilan jahit dan sulam siswa yang memiliki kemampuan berpikir kreatif tinggi dengan dari siswa yang memiliki kemampuan berpikir kreatif rendah; mengetahui interaksi penggunaan strategi pembelajaran dengan kemampuan berpikir kreatif dalam mempengaruhi hasil belajar Keterampilan jahit dan sulam. Metode penelitian yang digunakan adalah kuasi eksperimen. dengan sampel penelitian sebanyak 2 kelas yang ditentukan secara cluster random sampling terdiri dari kelas ekperimerimen yang diajarkan dengan strategi pembelajaran kooperatif tipe jigsaw dan strategi pembelajaran ekspositori. Hasil pengujian menunjukan : hasil belajar Keterampilan siswa yang di ajar dengan strategi pembelajaran jigsaw lebih tinggi dari pada siswa yang diajarkan dengan strategi ekspositori; hasil belajar Keterampilan siswa dengan Kemampuan berpikir kreatif tinggi lebih tinggi dari pada siswa dengan Kemampuan berpikir kreatif rendah; dan terdapat interaksi antara strategi pembelajaran dan kemampuan berpikir kreatif terhadap hasil belajar Keterampilan jahit dan sulam.
\end{abstract}

Kata Kunci: strategi pembelajaran, kemampuan berpikir kreatif, hasil belajar, keterampilan jahit dan sulam

\begin{abstract}
This research aimed to determine: the results of learning sewing and embroidery skills are taught using cooperative learning strategies jigsaw than students taught using expository teaching strategy, the results of learning sewing and embroidery skills of students who have a high ability to think creatively than students who have the ability to think creatively low, the interaction use learning strategies with creative thinking ability in influencing the outcomes of learning sewing and embroidery skills. Method is a mettod of quasi-experimental studi with a sampel of 2-class research ttah determined clucter random sampling exsperiment consists of classes taught cooperative learning strategies jigsaw and expository teaching strategy. The results showed: learning skills in teaching students with learning strategies jigsaw higher than students taught by expository strategy; Skills learning outcomes of students with high creative thinking ability is higher than the students with low ability to think creatively; and (3) there is interaction between Intructional strategy and creative thinking skills to the outcomes of learning sewing and embroidery skills.
\end{abstract}

Keywords: intructional strategy, creative thinking skills, outcomes of learning, sewing and embroidery skills

\section{PENDAHULUAN}

Sesuai dengan standar kompetensi kurikulum 2004 SMP tujuan mata pelajaran keterampilan adalah (1) Mengembangkan pengetahuan siswa melalui penelaah jenis, bentuk, sifat, dan penggunaan dan kegunaan alat proses dan teknik membuat berbagai produk kerajinan dan produk teknologi yang berguna bagi kehidupan manusia terhadap pengetahuan dan konteks budaya dari benda- benda asli (2) Mengembangkan kepekaan rasa estetika, rasa menghargai terhadap hasil produk kerajinan dan teknologi masa kini serta ersefak harus produk masa lampau dari berbagai wilayah nusantara dan dunia (3) Mengembangkan keterampilan siswa untuk menghasilkan produk kerajinan dari kehidupan manusia dalam menerapkan ilmu pengetahuan yang diperolehnya (4) Menanamkan apresiasi kepada siswa akan berbagai tatanan kehidupan 
termasuk budaya sehingga menumbuhkan kecintaan budaya berkarya yang berciri khas Indonesia (5) Mengembangkan kepekaan kreatif siswa melalui berbagai kegiatan penciptaan benda-benda produk penggunaan bahan alam maupun industri (6) Menumbuh kembangkan sikap profesional, kooperatif, toleransi, kepemimpinan (leadership), kekaryaan (employmentship), dan kewirausahaan (enterprenourship). (Depdiknas, 2004:7).

Dalam menyampaikan mata pelajaran Keterampilan permasalahan yang sering dihadapi adalah cara penyajian materi secara keseluruhan diharapkan lebih baik agar lebih mudah dipahami, dimengerti, dan siswa tidak merasa bosan dengan materi yang diberikan sebagai bekal dalam praktik berkarya, sehingga diperoleh hasil yang maksimal sesuai dengan tujuan pembelajaran yang diharapkan. Pemerintah sudah berusaha untuk meningkatkan mutu pendidikan salah satu cara yang dilakukan adalah memberikan pendidikan dan latihan (diklat) kepada guru dalam meningkatkan kompetensinya selain itu pemberian tunjangan sertifikasi juga diharapkan mampu untuk meningkatkan kesejahteraan guru sehingga meningkatkan kualitas guru dan pihak sekolah juga telah melakukan kegiatan yang diharapkan dapat meningkatkan kualitas guru dengan melaksanakan MGMP secara berkala setiap bulan serta kegiatan pelatihan yang dilakukan sekolah secara mandiri hal ini juga diharapkan mampu meningkatkan mutu pendidikan, namun pada kenyataannya mutu pendidikan di Indonesia dirasa masih rendah. Hal ini terlihat dari nilai ujian akhir sekolah sebagai salah satu tolak ukur masih rendahnya mutu pendidikan, khususnya mata pelajaran Keterampilan di SMP Negeri 3 Tanjung Morawa tahun pelajaran 2014 - 2015 yang menunjukkan bahwa hasil belajar siswa pada mata Keterampilan bahwa masih terdapat siswa yang memiliki nilai di bawah dari nilai KKM, hal ini tentunya kurang memuaskan. Kalaupun ada nilai yang mencapai KKM disebabkan faktor-faktor lain yang dijadikan guru sebagai pendukung nila tersebut, misalnya kehadiran, keaktifan, dan sikap siswa. Namun untuk nilai tes biasanya nilainya masih jauh dari yang diharapkan.

Hal tersebut dialami pada setiap materi dalam keterampilan salah satunya pada materi tentang membuat benda kerajinan jahit dan sulam. Realita yang dihadapi di sekolah, pembelajaran keterampilan kurang diperhatikan dan tidak mendapat penanganan dengan baik, dari segi waktu, sarana, dan media pembelajaran. Guru dan siswa menganggap pembelajaran keterampilan hanya sebagai pelengkap dari pembelajaran.

Slameto (2010:2) mengatakan belajar adalah suatu proses yang dilakukan seseorang untuk memperoleh suatu perubahan tingkah laku yang baru secara keseluruhan, sebagai hasil pengalamannya sendiri dalam interaksi dengan lingkungannya. Perubahan yang terjadi dalam diri seseorang banyak sekali, baik sifat maupun sejenisnya.

Hamid (2009:47) mengatakan bahwa belajar akan berjalan dengan baik jika apa yang hendak dipelajari itu atau masalah yang hendak dipecahkan diketahui ciri-cirinya. Suatu hal yang lebih tepat disajikan dalam urutan teratur, linear, sekeunsi, satu hal lain lebih tepat bila disajikan dalam bentuk terbuka dan memberi keleluasaan kepada para pebelajar untuk berimajinasi dan berpikir.

Hamalik (2008:155) "Hasil belajar merupakan gambaran perubahan tingkah laku pada diri siswa yang diamati dan diukur dalam bentuk perubahan pengertahuan, sikap, dan keterampilan". Perubahan tersebut dapat diartikan dengan terjadinya peningkatan dan kemajuan yang lebih baik jika dibandingkan dengan sebelum terjadi proses belajar. Selanjutnya Dalam Kamus Besar Bahasa Indonesia (KBBI) hasil belajar diartikan sebagai sebuah penguasaan pengetahuan atau keterampilan yang dikembangkan melalui mata pelajaran, lazimnya ditunjukkan dengan nilai tes atau angka nilai yang diberikan oleh guru. Hasil belajar dapat diartikan sebagai tingkat keberhasilan siswa dalam mempelajari materi pelajaran disekolah yang dinyatakan dengan skor yang diperoleh dari hasil tes mengenai sejumlah materi pelajaran tertentu (Alwasilah,2000).

Keterampilan adalah hasil belajar pada ranah psikomotorik, yang terbentuk menyerupai hasil belajar kognitif. Keterampilan adalah kemampuan untuk mengerjakan atau melaksanakan sesuatu dengan baik (Nasution, 1975: 28). Maksud dari pendapat tersebut bahwa kemampuan adalah kecakapan dan potensi yang dimiliki oleh seseorang untuk menguasai suatu keahlian yang dimilikinya sejak lahir. Kemampuan tersebut merupakan suatu hasil latihan yang digunakan untuk melakukan sesuatu. 
Keterampilan (skill) dalam arti sempit yaitu kemudahan, kecepatan, dan ketepatan dalam tingkah laku motorik yang disebut juga normal skill. Sedangkan dalam arti luas, keterampilan meliputi aspek normal skill, intelektual skill, dan social skill (Vembriarto, 1981:52). Keterampilan adalah pola kegiatan yang bertujuan, yang memerlukan manipulasi dan koordinasi informasi yang dipelajari (Sudjana,2010:17).

Berdasarkan pengamatan di lapangan strategi pembelajaran ekspositori dengan metode ceramah dan demonstrasi, demonstrasi selalu digunakan oleh guru dalam pelaksanaan pembelajaran karena dalam pelaksanaannya strategi ini sangat mudah untuk dilakukan pada materi Membuat benda kerajinan, guru hanya menyampaikan materi yang akan dipelajari secara lisan kepada siswa kemudian mendemonstrasikan materi yang disampaikan. Namun strategi ini kurang mendapatkan hasil yang maksimal jika digunakan dalam proses pembelajaran keterampilan, karena dalam pembelajaran keterampilan dibutuhkan kreatifitas, dan keterampilan siswa dalam menyelesaikan tugas yang diberikan guru.

Dalam hal ini dibutuhkan penggunaan
strategi pembelajaran yang dapat meningkatkan pemahaman dan keterampilan siswa, dengan strategi pembelajaran yang berorientasi pada aktifitas siswa yang menempatkan siswa sebagai subjek belajar dapat dipandang sebagai suatu pendekatan dalam pembelajaran yang menekankan pada aktivitas siswa secara optimal untuk memperoleh hasil belajar berupa perpaduan antara aspek kognitif, afektif, dan psikomotor yang seimbang sehingga hasil belajar yang maksimal dapat tercapai.

Selanjutnya menurut Syarifuddin (2014:107) strategi adalah suatu garis besar haluan dalam bertindak untuk mencapai sasaran yang akan ditentukan. Dihubungkan dengan belajr-mengajar, strategi bisa diartikan sebagai pola umum kegiatan guru-murid dalam perwujudan kegiatan belajar mengajar untuk mencapai tujuan yang ditetapkan.

Strategi pembelajaran terdiri atas seluruh komponen materi pembelajaran dan prosedur atau tahapan kegiatan belajar yang digunakan oleh tenaga pendidik dalam rangka membantu siswa mencapai tujuan pembelajaran tertentu. Dari konsep umum tersebut, strategi pembelajaran bisa dipahami dalam konteks khusus. Secara khusus strategi pembelajaran dipahami sebagai suatu cara atau seperangkat cata atau teknik yang dilakukan dan ditempuh oleh tenaga pendidik atau siswa dalam melakukan upaya terjadinya suatu perubahan tingkah laku atau sikap. Meskipun strategi pembelajaran adalah pendekatan menyeluruh pembelajaran dalam suatu sistem pembelajaran, namun diantara keutamaan itu, strategi dalam pengertian cara-cara khusus atau teknik yang lebih berorientasi pada kemampuan guru yang bisa lakukan ketak proses pembelajaran sedang berlangsung. Selanjutnya Morrison dan Kemp (2001:124) mengemukakan bahwa strategi pembelajaran sebagai suatu kegiatan pembelajaran yang harus dikerjakan guru dan siswa agar tujuan pembelajaran dapat dicapai secara efektif dan efisien.

Menurut Djamarah (2010:5) ada empat strategi dasar dalam pembelajaran yang harus diketahui oleh guru, yaitu: a) mengindentifikasi, menetapkan spesifikasi dan kualifikasi perubahan tingkah laku dan kepribadian anak didik sebagaimana yang diharapkan; b) memilih sistem pendekatan pembelajaran sebagai landasan filosofis dalam pembelajaran; c) memilih dan menetapkan prosedur, metode, dan teknik pembelajaran yang dianggap paling tepat dan efektif sehingga dapat dijadikan pegangan oleh guru dalam menunaikan kegiatan pembelajaran; d) menetapkan norma-norma dan batas minimal keberhasilan atau kriteria/standar keberhasilan sehingga dapat dijadikan pedoman oleh guru dalam melakukan evaluasi hasil kegiatan pembelajaran yang selanjutnya akan dijadikan umpan balik buat penyempurnaan sistem instruksional secara menyeluruh. (Djamarah, 2010: 327)

Salah satu alternatif strategi pembelajaran yang dapat meningkatkan kemampuan berpikir kreatif adalah strategi pembelajaran jigsaw. Strategi pembelajaran kooperatif jigsaw adalah sebuah model belajar kooperatif yang menitikberatkan kepada kerja kelompok siswa dalam bentuk kelompok kecil, seperti yang diungkapkan Lie (1993: 73), bahwa pembelajaran kooperatif model jigsaw ini merupakan model belajar kooperatif dengan cara siswa belajar dalam kelompok kecil yang terdiri atas empat sampai dengan enam orang secara heterogen dan siswa bekerja sama saling ketergantungan positif dan bertanggung jawab secara mandiri.

Dalam strategi pembelajaran jigsaw ini siswa memiliki banyak kesempatan untuk mengemukakan pendapat, dan mengelolah 
informasi yang didapat dan dapat meningkatkan keterampilan berkomunikasi, anggota kelompok bertanggung jawab atas keberhasilan kelompoknya dan ketuntasan bagian materi yang dipelajari, dan dapat menyampaikan kepada kelompoknya (Rusman, 2011:203).

Hal ini sesuai dengan hasil penelitian Rahim menunjukkan bahwa teknik jigsaw integrasi jurnal akademik dapat meningkatkan aktivitas belajar mahasiswa dari kategori cukup aktif menjadi kategori aktif, hasil belajar meningkat dari rata-rata $76,1 \%$ (kategori $\mathrm{B}$ ) menjadi rata-rata $91,7 \%$ (kategori $\mathrm{A}$ ), di samping menjadikan proses pembelajaran menjadi menyenangkan bagi mahasiswa, yang ditunjukkan oleh 54\% menyatakan sangat senang, dan $46 \%$ menyatakan senang dengan proses pembelajaran yang dialaminya.

Juga digunakan Strategi Pembelajaran Ekspositori, dimana menurut Sanjaya $(2011 ; 179)$ strategi pembelajaran ekspositori adalah strategi pembelajaran yang menekankan kepada proses penyampaian materi secara verbal dari seorang guru kepada sekelompok siswa degan maksud agar siswa dapat menguasai materi pelajaran secara optimal. Karakteristik strategi ekspositori: (1) Strategi ekspositori dilakukan degan cara menyampaikan secara verbal, artinya bertutur secara lisan mengunakan metode ceramah, (2) Biasanya materi pelajaran yang disampaikan adalah materi pelajaran yang sudah terjadi, seperti fakta, konsep-konsep tertentu yang harus dihafal sehingga tidak menuntut siswa untuk berifikir ulang, (3) Tujuan utama pembelajaran adalah pengusaan materi pelajaran itu sendiri. Artinya setelah proses pembelajaran berakhir siswa diharapkan dapat memahaminya degan benar dan dapat mengungkapkan kembali materi yang telah diuraikan.

Slameto (2003:163) menyatakan dalam strategi ekspositori, guru menyajikan materi yang harus dipelajari, memberikan jawabanjawaban, menyajikan prinsip-prinsip dan mengelaborasikan seluruh isi yang harus dipelajari. Pengajaran disini merupakan proses mengajar deduktif, dimulai dengan pemberian defenisi dari konsep, prinsip-prinsip yang akan diajar, menjelaskannya dan memberitahukan implikasi-implikasinya.

Dimyati \& Mudjiono (2009:172) menyatakan bahwa pembelajaran ekspositori, guru aktif memberikan penjelasan atau informasi terperinci tentang bahan pengajaran. Tujuan utamanya adalah "memindahkan" pengetahuan, keterampilan dan nilai-nilai kepada siswa. Peran guru dalam pembelajaran ini, adalah (1) penyusun program pembelajaran, (2) pemberi informasi yang benar, (3) pemberi fasilitas belajar yang baik, (4) pembimbing siswa dalam pemerolehan informasi yang benar, dan (5) penilai pemerolehan informasi.

Selain strategi pembelajaran, faktor lain juga perlu diperhatikan salah satunya adalah faktor kemampuan bepikir kreatif siswa. Berpikir kreatif dapat diartikan sebagai kemampuan berpikir untuk menemukan atau menghasilkan atau mengembangkan gagasan atau hasil yang asli, estetis dan kontruktif yang berhubungan dengan pandangan dan konsep yang penekanannya ada pada aspek berpikir intuisi dan rasional dalam menggunakan informasi untuk menjelaskan suatu maksud dengan prespektif asli pemikir, aktivitas berpikir kreatif memungkinkan lebih dari satu jawaban untuk menjawab berbagai masalah. Kemampuan berpikir kreatif peserta didik dalam pembelajaran perl dikembangkan untuk mencapai tujuan pendidikan. Kemampuan berpikir kreatif membentuk mengungkapkan gagasan orisinil untuk memecahkan masalah. Kemampuan berpikir kreatif yang dikembangkan dalam pembelajaran meliputi aspek keterampilan kelancaran (flexibility), keluwesan (fluency), keaslian (originality), penguraian (elaboration), dan perumusan kembali (redefinition) (Munandar 2009:20).

Nursito (2000:33) mengemukakan bahwa "berfikir kreatif akan muncul apabila seseorang melakukan aktifitas, bukan sesuatu yang mandiri atau berdiri sendiri, atau bukanlah semata-mata kelebihan yang dimiliki seseoran, berfikir kreatif merupakan bagian dari buah usaha seseorang dan menjadi seni ketika seseorang melakukan kegiatan". Sedangkan Hamalik (2008:180) mengemukakan bahwa berfikir kreatif sebagai "suatu bentuk dari proses pemecahan masalah".

Selanjutnya Munandar (2009:19) menyatakan bahwa berfikir kreatif merupakam "suatu gaya hidup, suatu cara dalam mempersepsi dunia, hidup kreatif berarti: mengembangkan talenta yang dimiliki, belajar menggunakan kemampuan diri sendiri secara optimal, menjajaki gagasan baru, tempat-tempat baru, mengembangkan kepekaan terhadap masalah lingkungan, masalah orang lain, dan masalah kemanusiaan".

Kreativitas adalah kemampuan seseorang untuk menciptakan sesuatu yang baru 
baik berupa gagasan maupun berupa karya yang relatif berbeda dengan apa yang telah ada sembelumnya (Ambarjaya, 2008). Kreativitas merupakan suatu kemampuan yang dimiliki seseorang dalam menciptakan suatu produk yang baru dengan mengubah cara lama dengan cara baru agar individu tersebut tidak terfokus pada satu hal saja.

Dalam proses pembelajaran sangatlah diharapkan kepada individu untuk mencari sumber yang banyak agar bisa menyelesaikan tugas atau permasalahan yang dihadapi. Ini juga dapat melihat sejauhmana individu dapat mengembangkan sesuatu yang baru apakah itu gagasan atau benda dalam bentuk rangkaian baru yang dihasilkan. Setiap proses pembelajaran disekolah, individu yang kreatif memiliki rasa ingin tahu yang tinggi sehingga banyak mengajukan pertanyaan, dan guru harus menghormati dan memperhatikan apa yang di tanyakan oleh individu tersebut, memberikan kesempatan kepada individu untuk berimajinasi tentang hal-hal yang belum pernah dilihat, menyukai hal-hal yang menantang, dan berani untuk mengambil resiko meskipun sangat sulit untuk dipecahkan, serta membelajarkan individu untuk saling menghargai antara satu sama lain atas hasil yang dicapai.

Masalah yang akan diteliti dalam penelitian ini dapat dirumuskan sebagai berikut: (1) Apakah strategi pembelajaran yang berbeda memberikan pengaruh yang berbeda terhadap hasil belajar Keterampilan jahit dan sulam?, (2) Apakah kemampuan berpikir kreatif yang berbeda memberikan pengaruh yang berbeda pula terhadap hasil belajar Keterampilan jahit dan sulam?, (3) Apakah ada interaksi penggunaan strategi pembelajaran dengan kemampuan berpikir kreatif dalam mempengaruhi hasil belajar Keterampilan jahit dan sulam?

\section{METODE}

Populasi dalam penelitian ini adalah seluruh siswa kelas VIII SMP Negeri 3 Tanjung Morawa. Adapun jumlah populasi pada penelitian ini adalah 286 orang. Populasi tersebut terbagi-bagi ke dalam beberapa kelompok (kelas), yakni dari kelas VIII-1 sampai kelas VIII-8. Teknik penentuan sampel digunakan cluster random sampling. Sampel penelitian dipilih secara acak dengan mengundi delapan kelas untuk mendapatkan dua kelas sebagai sampel penelitian. Desain penelitian menggunakan faktorial $2 \times 2$.

Penelitian ini menggunakan metode eksperimen dengan rancangan quasi eksperiment desain factorial $2 \times 2$. Melalui desain ini akan dibandingkan strategi pembelajaran kooperatif tipe jigsaw dan strategi pembelajaran ekspositori terhadap hasil belajar membuat benda kerajinan jahit dan sulam ditinjau dari siswa.

Teknik analisis data yang digunakan adalah teknik statistik deskritif dan inferensial. Teknik statistik deskriptif digunakan untuk mendeskripsikan data antara lai: nilai rata-rata (mean), median, modus, standard deviasi (SD) dan kecenderungan data. Teknik inferensial yang akan digunakan adalah teknik analisi data varians (ANAVA) 2 x 2. Pengujian hipotesisi dilakukan pada taraf signifikansi 5\%. sebelum Anava dua jalur dilakukan, terlebih dahulu dilakukan uji persyaratan Uji Chi Kuadrat, sedangkan uji persyaratan homogenitas menggunakan uji Barlett.

Jika dalam pengujian ANAVA ternyata terdapat interaksi strategi pembelajaran dan kemampuan berpikir kreatif) terhadap hasil belajar bahasa Indonesia yang signifikan, maka dilakukan uji lanjut. Dalam penelitian karena sampel tiap sel berbeda ( $\mathrm{n}$ berbeda) maka uji lanjut dilakukan dengan uji Scheffe.

Tabel 1. Desain Faktorial 2 x 2

\begin{tabular}{|c|c|c|}
\hline \multirow{2}{*}{$\begin{array}{c}\text { Kemampuan Berpikir } \\
\text { Kreatif(B) }\end{array}$} & \multicolumn{2}{|c|}{ Strategi Pembelajaran $(\mathrm{S})$} \\
\cline { 2 - 3 } & $\begin{array}{c}\text { Kooperatif tipe jigsaw } \\
\left(\mathrm{A}_{1}\right)\end{array}$ & $\begin{array}{c}\text { Ekspositori } \\
\left(\mathrm{B}_{2}\right)\end{array}$ \\
\hline Tinggi $\left(\mathrm{B}_{1}\right)$ & $\mathrm{A}_{1} \mathrm{~B}_{1}$ & $\mathrm{~A}_{2} \mathrm{~B}_{1}$ \\
\hline Rendah $\left(\mathrm{B}_{2}\right)$ & $\mathrm{A}_{1} \mathrm{~B}_{2}$ & $\mathrm{~A}_{2} \mathrm{~B}_{2}$ \\
\hline
\end{tabular}




\section{HASIL PENELITIAN}

Data hasil penelitian dikelompokkan berdasarkan interaksi strategi pembelajaran strategi pembelajaran dengan kemampuan berpikir kreatif siswa. Perbandingan kelompok data-data hasil belajar Keterampilan jahit dan sulam terangkum dalam tabel 2.

Tabel 2. Rangkuman Hasil Analisi Statistik Deskriptif

\begin{tabular}{|c|c|c|c|c|c|c|c|}
\hline \multirow{2}{*}{\multicolumn{2}{|c|}{ Variabel }} & \multicolumn{4}{|c|}{ Strategi Pembelajaran (A) } & \multirow{2}{*}{\multicolumn{2}{|c|}{ Total }} \\
\hline & & \multicolumn{2}{|c|}{$\begin{array}{c}\text { Strategi Pembelajaran } \\
\text { Jigsaw (A1) }\end{array}$} & \multicolumn{2}{|c|}{$\begin{array}{c}\text { Strategi Pembelajaran } \\
\text { Ekspositori (A2) }\end{array}$} & & \\
\hline \multirow{6}{*}{$\begin{array}{c}\mathrm{B} \\
\mathrm{E} \\
\mathrm{P} \\
\mathrm{I} \\
\mathrm{K} \\
\mathrm{I} \\
\mathrm{R}\end{array}$} & \multirow{6}{*}{$\begin{array}{c}\mathrm{T} \\
\mathrm{I} \\
\mathrm{N} \\
\mathrm{G} \\
\mathrm{G} \\
\mathrm{I} \\
\text { (B1) }\end{array}$} & $\mathrm{n}$ & 21 & $\mathrm{~N}$ & 17 & $\mathrm{~N}$ & 38 \\
\hline & & $\sum X$ & 1707 & $\sum X$ & 1312 & $\sum X$ & 3019 \\
\hline & & $\bar{X}$ & 81.2857 & & 77.1765 & $\bar{X}$ & 78.1316 \\
\hline & & $S^{2}$ & 41.1143 & $S^{2}$ & 43.0294 & $\mathrm{~S}^{2}$ & 44.9822 \\
\hline & & $\mathrm{S}$ & 6.4120 & $\mathrm{~S}$ & 6.5597 & $\mathrm{~S}$ & 6.7069 \\
\hline & & $\mathrm{X}^{2}$ & 139577 & $\mathrm{X}^{2}$ & 101944 & $\mathrm{X}^{2}$ & 241521 \\
\hline \multirow{6}{*}{$\begin{array}{c}\mathrm{K} \\
\mathrm{R} \\
\mathrm{E} \\
\mathrm{A} \\
\mathrm{T} \\
\mathrm{I} \\
\mathrm{F} \\
\text { (B) }\end{array}$} & \multirow{6}{*}{$\begin{array}{c}\mathrm{R} \\
\mathrm{E} \\
\mathrm{N} \\
\mathrm{D} \\
\mathrm{A} \\
\mathrm{H} \\
\text { (B2) }\end{array}$} & $\mathrm{n}$ & 15 & $\mathrm{~N}$ & 19 & $\mathrm{~N}$ & 34 \\
\hline & & $\sum X$ & 1128 & $\sum X$ & 1431 & $\sum X$ & 2559 \\
\hline & & $\bar{X}$ & 75.2000 & $\bar{X}$ & 75.3158 & $\bar{X}$ & 74.8529 \\
\hline & & $\mathrm{S}^{2}$ & 50.3143 & $\mathrm{~S}^{2}$ & 20.6725 & $\mathrm{~S}^{2}$ & 36.0686 \\
\hline & & $\mathrm{S}$ & 7.0933 & $\mathrm{~S}$ & 4.756 & $\mathrm{~S}$ & 6.0057 \\
\hline & & $X^{2}$ & 85530 & $X^{2}$ & 108149 & $X^{2}$ & 193679 \\
\hline \multirow{6}{*}{\multicolumn{2}{|c|}{ Total }} & $\mathrm{n}$ & 36 & $\mathrm{n}$ & 36 & $\mathrm{~N}$ & 72 \\
\hline & & $\sum X$ & 2829 & $\sum X$ & 2685 & $\sum X$ & 5578 \\
\hline & & $\bar{X}$ & 78.58 & $\bar{X}$ & 74.58 & $\bar{X}$ & 152.9845 \\
\hline & & $S^{2}$ & 43.68 & $S^{2}$ & 35.16 & $\mathrm{~S}^{2}$ & 81.0508 \\
\hline & & $\mathrm{S}$ & 6.61 & $\mathrm{~S}$ & 5.93 & $\mathrm{~S}$ & 12.7126 \\
\hline & & $\mathrm{X}^{2}$ & 223841 & $\mathrm{X}^{2}$ & 201487 & $X^{2}$ & 435200 \\
\hline
\end{tabular}

Setelah dilakukan kedua persyaratan penelitian dalam rangka penggunaan teknik analisis yakni uni normalitas dan uji analisis varians (ANAVA) telah dipenuhi, maka homogenitas, maka dapat dipastikan bahwa analisis tersebut dapat digunakan. persyaratan yang harus dipenuhi oleh data

Tabel 3. Rangkuman Hasil ANAVA

\begin{tabular}{|l|l|c|c|c|c|}
\hline \multicolumn{1}{|c|}{ Sumber variasi } & dk & JK & RJK & F & F $_{\text {tabel }}$ \\
\cline { 5 - 7 } & & & & $\mathbf{P = 0 , 0 5}$ \\
\hline Strategi pembelajaran & 1 & 288 & 288 & $\mathbf{8 . 1 1}$ & 3.98 \\
Kemampuan Berpikir Kreatif & 1 & 192.89 & 192.89 & $\mathbf{5 . 4 3}$ & 3.98 \\
Interaksi & 1 & 152.94 & 152.94 & $\mathbf{4 . 3 1}$ & 3.98 \\
Galat & 68 & 399.37 & 5.7053 & & \\
\hline Total & 72 & 1033.20 & & - & - \\
\hline
\end{tabular}

Perbedaan Hasil Belajar Keterampilan Jahit dan Sulam Antara Siswa yang Memperoleh Strategi Pembelajaran Jigsaw dan Ekspositori
Adapun hipotesis statistik yang diuji adalah:

Ho : $\mu A_{1} \leq \mu A_{2}$

На : $\mu A_{1}>\mu A_{2}$ 
Berdasarkan hasil pengujian hipotesis pada Tabel 3 di atas, maka diperoleh hasil perhitungan data strategi pembelajaran, dimana $\mathrm{F}_{\text {hitung }}=4,27$ sementara nilai kritik $\mathrm{F}_{\text {tabel }}$ dengan $\mathrm{dk}=(1,68)$ dan $\alpha=0,05$ adalah sebesar 3,98. Hasil ini menunjukkan bahwa $\mathrm{F}_{\text {hitung }}=4,27>$ $\mathrm{F}_{0,05}(1,70)=3,98$ sehingga hipotesis Nol $(\mathrm{Ho})$ ditolak dan menerima Ha. Dengan demikian dapat ditarik kesimpulan, bahwa hasil belajar Keterampilan jahit dan sulam siswa yang dibelajarkan dengan strategi pembelajaran jigsaw lebih tinggi dari hasil belajar Keterampilan jahit dan sulam siswa yang diajar dengan strategi pembelajaran ekspositori teruji kebenarannya secara empirik.

Perbedaan Hasil Belajar Keterampilan Jahit dan Sulam Antara Siswa yang Memperoleh Strategi pembelajaran Jigsaw Dan Ekspositori

Adapun hipotesis statistik yang diuji adalah:

Ho : $\mu B_{1} \leq \mu B_{2}$

На : $\mu B_{1}>\mu B_{2}$

Berdasarkan hasil pengujian hipotesis pada Tabel 3 di atas, maka diperoleh hasil perhitungan data kemampuan berpikir kreatif, dimana $\mathrm{F}_{\text {hitung }}=8,72$ sementara nilai kritik $\mathrm{F}_{\text {tabel }}$ dengan $\mathrm{dk}=(1,68) \quad$ dan $\alpha=0,05$ adalah sebesar 3,98. Hasil ini menunjukkan bahwa Fhitung $=8,72>\mathrm{F}_{0,05}(1,70)=3,98$ sehingga hipotesis Nol (Ho) ditolak. Dengan demikian dapat ditarik kesimpulan, bahwa hipotesis penelitian yang menyatakan hasil belajar Keterampilan jahit dan sulam siswa yang siswa yang mempunyai kemampuan berpikir kreatif tinggi lebih tinggi dari hasil belajar Keterampilan jahit dan sulam yang mempunyai kemampuan berpikir kreatif rendah dapat teruji kebenarannya secara empirik.

\section{Interaksi antara Strategi dengan Kemampuan berpikir kreatif terhadap Hasil Belajar Keterampilan Jahit dan Sulam.}

Adapun hipotesis statistik yang diuji adalah:

Ho : A X B $=0$

Ha: A X B $\neq 0$

Berdasarkan hasil pengujian di atas diperoleh hasil perhitungan interaksi strategi dengan kemampuan berpikir kreatif, dimana $F_{\text {hitung }}=5,03$ sementara nilai kritik $F_{\text {tabel }}$ dengan $\mathrm{dk}=(1,68)$ dan $\alpha=0,05$ adalah sebesar 3,98. Hasil ini menunjukkan bahwa $\mathrm{F}_{\text {hitung }}=5,03>$ $\mathrm{F}_{0,05}(1,70)=3,98$ sehingga hipotesis $\mathrm{Nol}(\mathrm{Ho})$ ditolak dan menerima ha. Dengan demikian dapat ditarik kesimpulan, bahwa hipotesis penelitian yang menyatakan terdapat interaksi antara strategi dengan kemampuan berpikir kreatif terhadap hasil belajar Keterampilan jahit dan sulam teruji kebenarannya secara empirik.

Untuk melihat bentuk interaksi antara strategi pembelajaran pembelajaran dan kemampuan berpikir kreatif dalam mempengaruhi hasil belajar Keterampilan jahit dan sulam, dilakukan uji lanjut dengan menggunakan uji Scheffe. Ringkasan hasil uji Scheffe dapat dilihat pada Tabel 4 di bawah ini.

Tabel 4 Ringkasan Hasil Uji Scheffe

\begin{tabular}{|c|l|l|l|c|l|}
\hline No & \multicolumn{2}{|c|}{ Interaksi } & $\mathrm{F}_{\text {Hitung }}$ & $\begin{array}{c}\mathrm{F}_{\text {Tabel }} \\
\alpha=0.05\end{array}$ & Keterangan \\
\hline $\mathbf{1}$ & $\mu \mathrm{A}_{1} \mathrm{~B}_{1}$ & $\mu \mathrm{A}_{2} \mathrm{~B}_{1}$ & 2.95 & 2.72 & Signifikan \\
\hline $\mathbf{2}$ & $\mu \mathrm{A}_{1} \mathrm{~B}_{1}$ & $\mu \mathrm{A}_{2} \mathrm{~B}_{2}$ & 3.14 & 2.72 & Signifikan \\
\hline $\mathbf{3}$ & $\mu \mathrm{A}_{1} \mathrm{~B}_{1}$ & $\mu \mathrm{A}_{1} \mathrm{~B}_{2}$ & 3 & 2.72 & Signifikan \\
\hline $\mathbf{4}$ & $\mu \mathrm{A}_{2} \mathrm{~B}_{1}$ & $\mu \mathrm{A}_{2} \mathrm{~B}_{2}$ & 0.93 & 2.72 & Tidak Signifikan \\
\hline $\mathbf{5}$ & $\mu \mathrm{A}_{2} \mathrm{~B}_{2}$ & $\mu \mathrm{A}_{2} \mathrm{~B}_{1}$ & 0.93 & 2.72 & Tidak Signifikan \\
\hline $\mathbf{6}$ & $\mu \mathrm{A}_{2} \mathrm{~B}_{2}$ & $\mu \mathrm{A}_{1} \mathrm{~B}_{2}$ & 0.06 & 2.72 & Tidak Signifikan \\
\hline
\end{tabular}

Hasil pengujian lanjut di atas, menunjukkan adanya interaksi antara strategi pembelajaran dan kemampuan berpikir kreatif terhadap hasil belajar keterampialn jahit dan sulam siswa kelas VIII SMP Negeri 3 Tanjung Morawa. Interaksi strategi pembelajaran dan kemampuan berpikir kreatif dapat ditunjukkan seperti pada Gambar 1 berikut. 


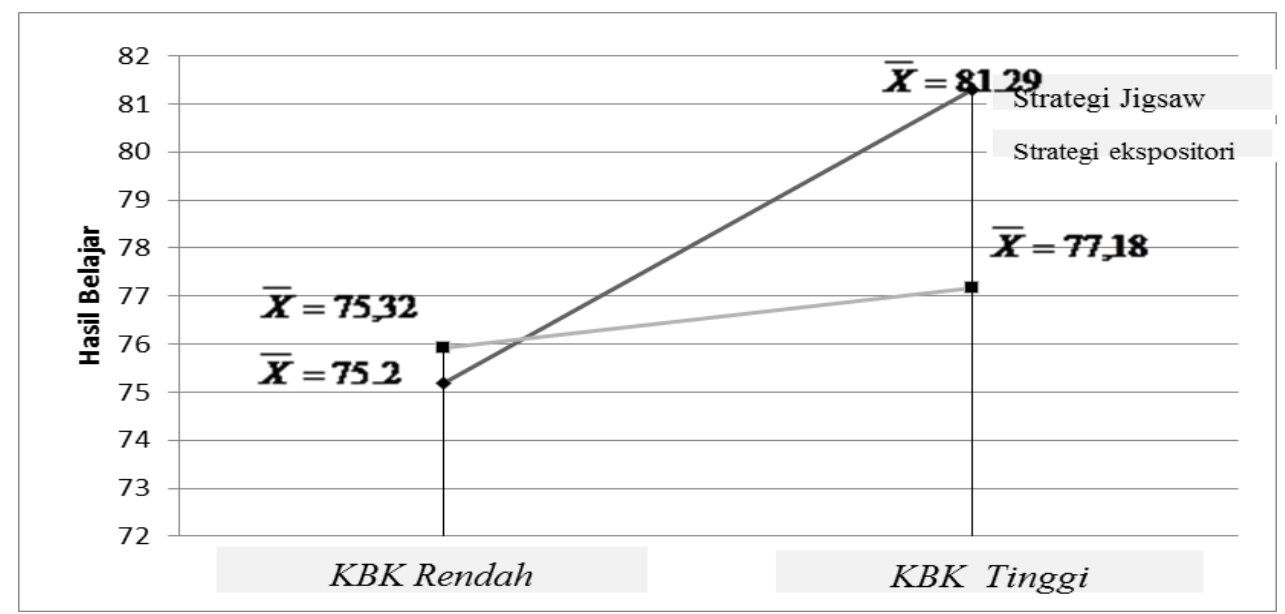

Gambar 1. Interaksi antara Strategi Pembelajaran dan Kemampuan Berpikir Kreatif

\section{PEMBAHASAN}

Rata-rata hasil belajar Keterampilan jahit dan sulam siswa diajar dengan strategi pembelajaran Jigsaw lebih baik daripada ratarata hasil belajar siswa yang diajar dengan strategi pembelajaran ekspositori. Hal ini menunjukkan bahwa strategi jigsaw terbukti efektif dapat meningkatkan hasil belajar siswa secara keseluruhan baik untuk kemampuan berpikir kreatif. Dari hasil temuan ini menunjukkan bahwa untuk mengajarkan materi ajar Keterampilan jahit dan sulam lebih baik menggunakan strategi pembelajaran jigsaw daripada dengan strategi pembelajaran ekspositori. Hal ini dapat dimaklumi karena pembelajaran jigsaw siswa belajar dalam kelompok kecil yang memiliki tingkat kemampuan yang berbeda. Sebagaimana dijelaskan Slavin (1995) mengemukakan: "In cooperative learning methods, students work together in four member teams to master material initially presented by the teacher". Dan Lie (2000) menyatakan bahwa pembelajaran koperatif adalah sistem pembelajaran yang member kesempatan kepada peserta didik untuk bekerjasama dengan siswa lain dalam tugas-tugas yang terstruktur. Dalam menyelesaikan tugas kelompok, setiap anggota saling bekerja sama dan membantu memahami suatu bahan pembelajaran artinya belajar belum selesai jika salah satu teman dalam kelompok belum menguasai bahan pembelajaran.

Temuan penelitian ini mendukung penelitian yang dilakukan: (1) Bukunola and Daniel Idowu (2005), menemukan bahwa siswa dengan dua strategi pembelajaran kooperatif (Belajar Bersama dan Jigsaw) kelompok memiliki hasil lebih tinggi hasil prestasi akademik dari siswa dalam kelompok konvensional-ceramah. Belajar bersama dan strategi pengajaran kooperatif Jigsaw ditemukan menjadi lebih efektif dalam meningkatkan prestasi akademik siswa lebih baik dari konvensional-kuliah, dan (2) dapat meningkatkan hasil belajar membaca Al-Qur'an siswa kelas IV-B MIN Glugur Darat Medan hal ini ditunjukkan dengan adanya peningkatan aktifitas siswa dalam berdiskusi selama pembelajaran berlangsung.

Strategi pembelajaran jigsaw dapat mendorong siswa untuk aktif belajar karena siswa dapat bekerja sama dengan baik di dalam kelompoknya, seperti menjadi pendengar yang baik, siswa diberi lembar kegiatan yang berisi pertanyaan atau tugas yang direncanakan untuk diajarkan. Selama kerja kelompok, tugas anggota kelompok adalah mencapai ketuntasan, sehingga siswa yang diajar dengan strategi pembelaajran jigsaw dapat meningkat hasil belajar siswa karena dengan belajar secara kelompok dalam situasi yang heterogen kemampuannya membuat siswa akan dapat saling mempengaruhi dan saling bersosialisasi sehingga memicu aktivitas belajar siswa menjadi lebih baik, siswa dapat memahami konsep-konsep yang mungkin sulit dimengerti apabila siswa hanya mempelajarinya secara individual. Belajar dalam kelompok membuat siswa saling berinteraksi, yang lebih pintar dapat member penjelasan kepada yang lamban, dan sebaliknya yang lamban bisa bertanya kepada yang paham sehingga mereka dapat saling mengisi dan memotivasi diri mereka sendiri untuk dapat bekerja sama tetapi juga bertanggung jawab untuk memperbaiki nilai masing-masing. Oleh karena itu peran guru dalam pembelajaran jigsaw sebagai fasilitator 
yang mengarahkan siswa untuk menemukan dan mengkonstruksi sendiri pengetahuannya

Siswa yang memiliki kemampuan berpikir kreatif tinggi lebih mampu memahami pelajaran Keterampilan jahit dan sulam dibandingkan siswa yang memiliki kemampuan berpikir kreatif rendah. Hasil penelitian ini sesuai dengan Penelitian Hero (2011), menuliskan bahwa hasil penelitiannya mengenai pengaruh strategi pembelajaran dan kemamapuan berfikir kreatif terhadap hasil belajar menggambar ekspresi siswa SMA Negeri 2 Kota Pematang Siantar. Hasil penelitian ini diperoleh bahwa hasil belajar menggambar ekspresi siswa yang memiliki kemampuan berfikir kreatif tinggi lebih tinggi dari pada siswa yang memiliki kemampuan berfikir kreatif rendah.

Seperti dijelaskan sebelumnya bahwa selain dari faktor yang berasal dari luar diri siswa faktor dari dalam diri siswa juga menjadi faktor yang mempengaruhi hasil belajar siswa. Salah satu faktor yang berasal dari dalam diri siswa adalah kemampuan berpikir kreatif.

Kemampuan berpikir kreatif merupakan kemampuan siswa dalam memahami masalah dan menemukan penyelesaian dengan strategi atau metode yang bervariasi (divergen). Berpikir kreatif dapat menumbuhkan ketekunan disiplin dan berlatih penuh, meliputi aktivitas mental, mangajukan pertanyaan mempertimbangkan informasi baru dan ide yang tidak lazim dengan pemikiran terbuka. Berpikir kreatif memiliki karakteristik diantaranya adalah kemampuan mengolah informasi yang dibutuhkan, memikirkan sasaran informasi yang dipergunakan dalam memproses informasi yang diperoleh serta mengaplikasikannya dalam pemecahan masalah sampai kepada sejauh mana informasi yang diperoleh mampu dikembangkan menjadi bekal dalam menginovasikan hal baru.

Sedangkan siswa yang memiliki daya kreatif yang rendah membutuhkan waktu dan pembelajaran lebih lama untuk menjelaskan materi pelajaran dibadingkan dengan siswa yang memiliki daya kreatif tinggi. Artinya siswa tersebut mambutuhkan waktu dalam membangun dan menemukan konsep, kemampuan serta pengetahuan yang dibutuhkan dalam belajar. Selalin itu siswa dengan kemampuan berpikir kreatif rendah tidak memiliki daya imajinasi yang cukup memadai untuk mengkonstruksi gambar motif ragam hias, sehingga lebih sulit dalam memahami pelajaran. Siswa ini tidak suka dengan tantangan dan cenderung tidak percaya diri, mereka cenderung tidak suka terlibat secara aktif dalam kegiatan pembelajaran di kelas.

Aktualisasi kemampuan berpikir kreatif siswa dalam pembelajaran memungkinkan keterlibatan aktif siswa sehingga dapat meningkatkan kebermaknaan proses pembelajaran dan efektifitas belajar mandiri untuk mencapai hasil belajar yang lebih baik.

Hasil belajar yang optimal akan diperoleh apabila beragam perbedaan seperti kebiasaan, minat, gaya belajar, dan kemampuan berpikir kreatif peserta didik diakomodsai oleh guru memalui pemilihan metode dan materi yang sesuai. Pembelajaran bidang studi apapun dapat ditingkatkan kualitasnya apabila tenaga pendidik memahami karakteristik peserta didik dengan baik kemampuan berpikir kreatif. Kemudian, informasi tentang peserta didik tersebut menjadi bahan pertimbangan bagi guru dalam memilih metode dan materi saja yang sesuai dengan keberagaman potensi peserta didik.

Keterkaitan antara strategi pembelajaran dan kemampuan berpikir kreatif siswa dalam situasi pembelajaran adalah hal yang sangat perlu diperhatikan. Siswa dengan kemampuan berpikir kreatif tinggi yaitu terbuka terhadap pengalaman baru, luwes dalam berfikir dan bertindak, bebas dalam mengekspresikan fantasi, beminat pada kegiatan kreatif, percaya pada gagasan sendiri dan mampu memahami, mengklasifikasi, mengaplikasi aturan atau prinsip dalam sebuah pola atau urutan gambar, serta mengidentifikasi hubungan dalam satu pasangan gambar.

Tingkat kemampuan berpikir kreatif tinggi yang dimiliki siswa dapat membuatnya lebih efektif belajar dengan dukungan strategi pembelajaran yang tepat. Semakin tinggi kemampuan berpikir kreatif siswa maka diharapkan siswa tersebut semakin aktif dan mempunyai kammpuan dalam mengaitkan ideide yang dimiliki dengan materi yang baru diterimanya. Tujuan akhir siswa dapat diharapkan menyelesaikan masalah-maslah pelajran yang dihadapi.

Siswa dengan kemampuan berpikir kreatif tinggi pada umumnya suka dengan pelajaran Keterampilan karena mereka cenderung memiliki rasa ingin tahu yang lebih besar dan merasa tertantang melakukan berbagai kegiatan untuk secara langsung terlibat dalam berbagai pengalaman belajar, mereka memiliki daya imanjinasi yang tinggi untuk mengkonstruksi 
gambar motif ragam hias menjadi lebih mudah untuk dipahami dan memiliki kemampuan berpikir kreatif tinggi untuk menerapkan bermacam-macam tusuk menghias kain menjadi benda kerajinan jahit dan sulam. Berbagai keterbatasan dalam proses belajarnya bukan hambatan bagi dirinya untuk mengeksplorasi pengetahuan dengan lebih mandiri dalam belajar, serta komitmen tinggi untuk mencapai cara-caranya sendiri. Sehingga diduga siswa dengan kemampuan berpikir kreatif tinggi dan diajar dengan strategi pembelajaran kooperatif tipe jigsaw akan lebih efektif untuk meningkatkan hasil belajarnya secara optimal. Sebaliknya jika siswa yang memiliki kemampuan berpikir kreatif tinggi dan diajar dengan strategi pembelajaran ekspositori diduga prestasi belajarnya akan lebih rendah, sebab strategi ini didominasi oleh guru sehingga siswa yang memiliki kemampuan berpikir kreatif tinggi untuk mengetahui sebab-sebab dari suatu persoalan dengan kemampuan yang dimilikinya tidak terrealisasi dengan baik dan hal ini menyebabkan siswa tersebut merasa jenuh dan bosan dalam belajar sehingga mengakibatkan hasil belajarnya menjadi rendah.

Sementara itu siswa yang memiliki kemampuan berpikir kreatif rendah justru sebaliknya, mereka tidak terbuka terhadap pengalaman baru dan cenderung menutup diri dan tidak suka menerima tantangan, kaku dalam berfikir dan bertindak, tidak berani mengekspresikan diri dan cenderung ikutikutan, kurang mandiri dan tidak percaya diri dengan gagasan sendiri, hal ini dapat dilihat dari ketidakmampuannya memahami, mengklasifikasi, mengidenifikasi, mengaplikasi kan aturan atau prinsip dalam sebuah pola atau urutan bentuk gambar serta mengkonstruksi gambar motif ragam hias, dan ketidak mampuan untuk menerapkan bermacam-macam tusuk menghias kain menjadi benda kerajinan jahit dan sulam.

Siswa dengan kemampuan berpikir kreatif rendah bila diajar dengan strategi pembelajaran kooperatif tipe jigsaw kurang meningkatkan hasil belajarnya, sebab strategi ini didesain bukan hanya untuk meningkatkan rasa tanggung jawab siswa terhadap pembelajarannya sendiri tetapi juga terhadap pembelajaran orang lain. Siswa tidak hanya mempelajari materi yang diberikan, tetapi mereka juga harus siap memberikan dan mengajarkan materi tersebut kepada kelompoknya. Dengan demikian siswa yang memiliki kemampuan berpikir kreatif rendah dalam proses pembelajarannya, strategi pembelajaran ekspositori akan lebih efektif digunakan untuk meningkatkan hasil belajarnya, sebab langkahlangkah yang digunakan dalam strategi ekspositori sesuai dengan karakteristik siswa yang memiliki kemampuan berpikir kreatif rendah, tidak berani menekspretikan diri sendiri dan cenderung ikut-ikutan, kurang mandiri dan tidak percaya diri dengn gagasan sendiri, tidak mampu memahami, mengklasifikasi, mengidentifikasi, mengaplikasikan aturan atau prinsip dalam sebuah pola atau urutan bentuk gambar serta tidak mampu mengkonstruksi gambar motif ragam hias, dan tidak mampu untuk menerapkan bermacam-macam tusuk menghias kain menjadi benda kerajinan jahit dan sulam. Dengan demikian pembelajaran dengan menggunakan Strategi jigsaw lebih tepat dibelajarkan kepada siswa yang memiliki kemampuan berpikir kreatif tinggi dan pembelajaran dengan menggunakan Strategi pembelajaran ekspositori lebih tepat untuk siswa yang memiliki kemampuan berpikir kreatif rendah.

\section{PENUTUP}

Simpulan hasil penelitian ini adalah sebagai berikut:

1. Hasil belajar keterampilan jahit dan sulam siswa dengan strategi pembelajaran tipe jigsaw lebih baik dibandingkan dengan strategi pembelajaran ekspositori. Dalam hal ini siswa yang dibelajarkan dengan menggunakan strategi pembelajaran tipe jigsaw lebih baik dibandingkan dengan hasil belajar siswa yang dibelajarkan dengan strategi pembelajaran ekspositori.

2. Hasil belajar siswa yang memiliki kemampuan berpikir kreatif tinggi lebih baik dibandingkan dengan hasil belajar siswa yang memiliki kemampuan berpikir kreatif rendah. Dengan demikian siswa yang memiliki kemampuan berpikir kreatif tinggi memperoleh hasil belajar keterampilan jahit dan sulam yang lebih baik dibandingkan dengan siswa yang memiliki kemampuan berpikir kreatif rendah.

3. Terdapat interaksi antara strategi pembelajaran dengan kemampuan berpikir 
kreatif yang memberikan perbedaan pengaruh terhadap hasil belajar keterampilan jahit dan sulam, hal ini terbukti dari hasil penelitian yang menunjukan bahwa bagi kelompok siswa yang memiliki kemampuan berpikir kreatif tinggi memperoleh nilai lebih baik bagi siswa yang diajar dengan strategi pembelajaran tipe jigsaw, sedangkan bagi siswa yang memiliki rendah memperoleh nilai lebih baik bagi siswa yang kemampuan berpikir kreatif diajar dengan strategi pembelajaran ekspositori.

\section{DAFTAR PUSTAKA}

Ahmadi, Abu dan Uhbiyati.2001. Ilmu Pendidikan Cetakan II. Jakarta: Rineka Cipta.

Anita Lie. 2007. Kooperatif Learning (Mempraktikkan Cooperative Learning diRuang-ruang Kelas). Jakarta: Grasindo.

Ahmadi, A., Nur Uhbiyati. 2001. "Interaksi Belajar Mengajar". Remaja Karya.Bandung.

Ambarjaya.S, Beni. (2008). Model-model Pembelajaran Kreatif. Bandung: TintaEmas Publishing.

Anderson, dkk.2010. Kerangka Landasan untuk Pembelajaran, Pengajaran, dan Asesmen (Revisi Taksonomi Pendidikan Bloom). Yogyakarta: Pustaka.

Anastasi, A. 2007. Psychological Testing.New Jersey: Prentice Hall.

Arikunto, S.2005. Dasar-Dasar Evaluasi Pendidikan.Jakarta: Bumi Aksara.

Burton, W. H. 2002. The Guindance of Learning Activites. New York: Appleton Century Coffs, Inc.

Dick, W and L. Carey, J. O. Carey. 2005. The sistematic Design of Instruction. New York: Logman.

Djamarah, dkk. 2010. Strategi belajar mengajar. Jakarta: Rineka cipta

Dimyati dan Mudjiono. 2009. Belajar dan Pembelajaran. Jakarta: Rineka Cipta

Fudyartanta, RBS., (2002). Psikologi Pendidikan, Glogal Pustaka Utama, Jakarta.

Gagne, R. \& Briggs, L. 1979 Principle of Instructional Design. New York: Holt, Rinehart and Winston.

Hamalik, O. 2008. Perencanaan Pengajaran; berdasarkan Pendekatan Sistem.Jakarta: Bumi Aksara.
Hamid. 2009. Teori Belajar dan Pembelajaran. Medan.

Margono. 2007. Pendidikan Keterampilan: SMP Kelas VIII.Bogor: Yudistira.

Morison G. R., Ross S.M., \& Kemp J.E. 2001. Designing Effective instruction. Third Edition. New york. Chester. Weinheim. Brisbane. Toronto.Singapore: John Wiley \& sons, Inc.

Muhammad Nadeem Anwar, dkk. 2012. Relationship of Creative Thinking with the Academic Achievements of Secondary School Students.University of Sargodha. Pakistan: Journal.

Munandar, U. 2009. Pengembangan Kreatifitas Anak Berbakat. Jakarta: Rineka Cipta.

Nursito 2000. Menggali Kreatifitas. Jakarta: Mitra Gama Widya.

Roestiyah, 2008. Strategi Belajar Mengajar. Jakarta: Rineka Cipta.

Rusman. 2011. Model-model Pembelajaran. Jakarta: Rajawali Pers

Sadiman, A. M., (2003). Motivasi Belajar dan Intrucsional, Rajawali, Jakarta.

Slameto. 2010. Belajar dan Faktor-Faktor yang Mempengaruhinya. Jakarta: Rineka Cipta.

Sanjaya, W. 2010. Strategi pembelajaran Berorientasi standar Proses Pendidikan. Jakarta: Kencana.

Semiawan, C. 1997. Perspektif Pendidikan Anak Berbakat. Jakarta: Gramedia.

Soemantri, V.M. Bambang. 2005. Tusuk Sulam Dasar. Jakarta: Gramedia Pustaka Utama.

Sudijono, A. 2009. Pengantar Evaluasi Pendidikan. Jakarta: Rajawali Pers.

Suparman, A. 2012. Desain Instruksional Modern. Jakarta: Erlangga.

Trianto. 2010. Mendesain Model Pembelajaran Inovatif Progresif. Jakarta: Kencana. 